\title{
Analysis of the Development of Financial Risk Management of the Enterprise in Kazakhstan
}

\author{
B. M. Aliyeva ${ }^{1}$, M. T. Zholamanova ${ }^{1} \&$ Zh. K. Zhorabayeva ${ }^{1}$ \\ ${ }^{1}$ al-Farabi Kazakh National Univeristy, Almaty, Kazakhstan \\ Correspondence: B. M. Aliyeva, al-Farabi Kazakh National Univeristy, Almaty, Kazakhstan. E-mail \\ info@kaznu.kz
}

Received: June 23, 2015 Accepted: July 7, 2015 Online Published: August 18, 2015

doi:10.5539/ass.v11n24p315 URL: http://dx.doi.org/10.5539/ass.v11n24p315

\begin{abstract}
In this scientific article based on the study of problems of effective management of financial risks of Kazakhstani companies and "KazMunaiGas" JSC were identified the main risks, which typical for Kazakhstan's financial market at the present stage of its development, was justified the feasibility of using indicators to measure the level of financial risks on the basis of the comparative analysis based on the VaR methodology, as well as the expediency of the use of futures and options contracts to hedge the financial risks of the companies.
\end{abstract}

Keywords: financial risk management, KMG JSC, Value at Risk, hedging of financial risks, futures and options contracts

\section{Introduction}

One of the most important elements of a market economy is the financial market, the formation and intensive development in Kazakhstan which has become an integral and constituent part of the complex and multifaceted process of restructuring of economic relations. However, the unstable nature of economic processes in the country, the imperfection of the system of management of financial market and its legislative and regulatory framework, increasing its dependence on fluctuations in world market conditions and other factors imply the existence of high risks to economic entities operating on the Kazakhstan financial market. The problem of financial risk management is a key in business. It is associated with loss of the stable financial position of the company in the process of activity and is the main element to making any economic decisions. Therefore, it is very important to study emerging in the company's financial risks and the identification of methods and techniques for their management. The research is based on methodological and theoretical development of the control systems and financial risk assessment presented in the works of Russian and foreign scientists, who focus on the problems of financial risk management, focusing on the internal mechanisms of neutralisation of financial risks.

Among the research works on the issue is needed in the area of financial management and risk analysis to note the research papers of Balabanov I. T., Burenina A. N., Vorontsov A. V., Kandinsky O. A., Kasimova Y. F., Kuznetsov M. V., Lobanov A. A., Lukashin Y. P., Mirkin Y. M., Mikhailova M. D., Pervozvansky T. N., Pervozvansky A. A., Rogov M. A., Chetyrkin E. M., Alexander G., Braley R., Brigham Y., Braly J., Van Horne J., O Gapenski L., L. Galicia, Gloriana P., Douglas L., Myers C., Marshall J., Mishra V., F. Knight, Paramo K., Penza, P., Rudolf M., Raja K., Smith K., Willota P., Waltham J., Fabozzi F., Sharpe W. As an independent research area in financial risk assessments should provide financial econometrics, models and methods which allow us to estimate the main parameter of financial risk - volatility. Their development is devoted to research papers of Ayvazyan C., Yelisseyeva I., Mkhitaryan V., Bacalava L., Green M., Campbell J., Lo V., McKinley A., Taylor C., and Kazakh scientists Baymuratov W. B., Chelekbay A. D., Abdrakhmanova G. T., U. M. Iskakova, M. U. Spanova.

However, despite a number of significant theoretical results in this area, their applicability on the Kazakhstan stock market does not guarantee its participants financial losses. All this raises a number of significant scientific problems improvement and formation of approaches to the assessment and management of financial risks, adequate to the conditions of Kazakhstan's financial market that causes the relevance of the dissertation research. 


\section{Method}

Analyzing Kazakhstan's experience in risk management, most companies see the obvious need for a comprehensive risk management system. Many companies have implemented this process or be at a stage of active implementation. So according to the static data of independent experts $66 \%$ of companies in the Republic of Kazakhstan introduced the position of a risk Manager, and 21\% are going to introduce this feature in next year. $30 \%$ and $35 \%$ of companies, respectively, allocated in their organizational structures the Commission and the Committee of Directors on risk management.

In $47 \%$ the companies of an obligation for the organization and support of process of management of risks are assigned to the risk manager. Also results of poll showed that in $18 \%$ of the companies the head of internal audit that doesn't correspond to the best world practices on ensuring independence of internal audit is responsible for process of the organization of risk management. The CEO is responsible for process of management of risks only in $12 \%$ of the companies. Thus, $24 \%$ of risk managers are formally subordinated to the CEO, and functionally to committee of audit.

In the countries of Asia, Australia, Western Europe and North America the top management of the companies is actively involved in process of management of risks, and the organization of this process is assigned to the CEO. Obvious distinction in approach to risk management in the Kazakhstan companies can be explained by distinction in culture of understanding of risk management at top management of the companies. Thus, it is necessary to consider that in countries of Western Europe function of the risk manager of the companies to be at higher step of administrative hierarchy than in Kazakhstan. In the majority of the companies of Asia, Australia, Western Europe risk managers are a part of the top executive management. In Kazakhstan function of the risk manager quite often joins in structure of department of internal audit with direct submission to the director of internal audit of the company.

\section{Results}

In spite of the fact that the majority of the companies declare active introduction of process of management of risks, many companies don't know a threshold of risks, which the company in case of approach of negative events is capable to sustain that can lead to not predicted monetary losses and failures of projects.

As in any management process, in process of management of risks companies face certain obstacles in a way of creation of an effective control system of risks. So, as the main barriers interfering effective management of risks the Kazakhstan companies (57\%) allocate insufficient interrelation between functional divisions of the company regarding risk management, and also absence of corporate culture of risk management. While for the western companies poor quality of the received information (43\%) and impossibility of receiving an exact assessment of risks of the company (36\%) were called the most essential barriers. For the Kazakhstan companies poor quality of the received information only on the third place (45\%), but not possibility of receiving an exact assessment of risks of the company (31\%).

One of the barriers, which is seriously interfering to development of control system of risks, many companies call low efficiency of the applied techniques of identification, an assessment and risk management. This result can be caused by control systems of risks, which are insufficiently formalized and integrated. At implementation of programs for reduction of expenses many companies don't employ third-party consultants and don't see sense in introduction of the software for identification, an assessment and risk management, preferring to consult own forces. The lack of financial resources was noted $12 \%$ of the companies as one more barrier disturbing to increase process efficiency of risk management. Thus, insufficient process formalization of risk management and lack of experience in area lead a risk management to that the majority of the companies of real sector of economy at an assessment of risks generally rely on experience of experts. Exact quantitative techniques of risk assessment are used insufficiently widely. It can be explained with lack of sufficient volume of statistical data on cases of realization of these or those that is necessary for carrying out an exact quantitative assessment. On the other hand, low preparation of the personnel of the companies in the field of risk management as was noted earlier, also significantly slows down introduction of quantitative techniques in the companies.

Organizational-economic characteristics of the JSC "Exploration Production "KazMunaiGas". JSC "Exploration Production "KazMunayGas" ("KMG") is one of the leaders of oil production in Kazakhstan. The company is a producer of oil, natural gas and associated gas from its own hydrocarbon reserves on the deposits in the western and southern regions of Kazakhstan.

The company was formed in March 2004 through the merger of JSC Uzenmunaigas (UMG) and Embamunaigas (EMG). After a successful initial offering of the capital on the London and Kazakhstan stock exchanges at the 
end of 2006, through clever implementation of acquisition policies, programs, investments in fixed assets and effective measures to optimize costs, KMG has considerably strengthened its position in both domestic and international markets. In its IPO in September 2006 the company has attracted more than 2 billion USD. "KMG" is a subsidiary of the national oil company of the Republic of Kazakhstan - JSC "National Company "KazMunayGas" (KMG NC), which owns 60.5 per cent of the common shares of KMG as at 31 December 2012 (Figure 1).

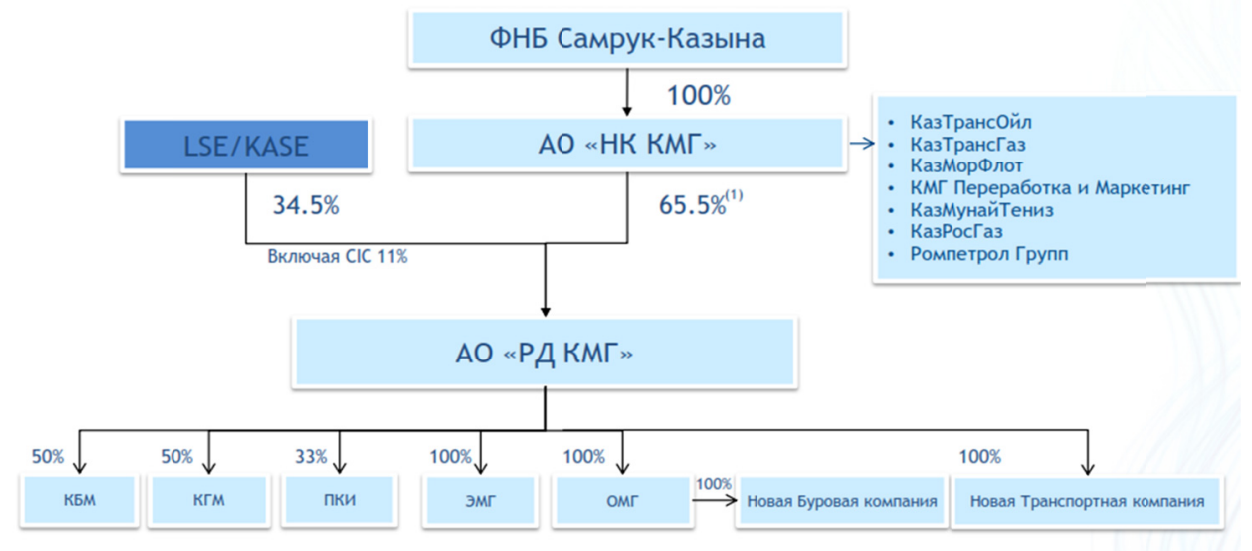

Figure 1. Structure EP "KazMunaiGas"

JSC "Exploration Production "KazMunaiGas" is also actively implementing a program of exploration work to maintain and develop the resource base and develops the 41 fields in Western Kazakhstan. The total area of the fields is $837,4 \mathrm{~km} 2$. Production units of the company have been operating for over 90 years. Key production assets of the Company are two industrial branches: UMG and EMG, with general level of production 177 thousand barrels of oil per day in 2010. The Uzen field is the largest in the portfolio of core assets of KMG, it accounts for $73 \%$ of all stocks and $68 \%$ of the total mined production.

One of the main objectives of KMG is the growth of hydrocarbon reserves. This growth is possible thanks to the acquisitions of new assets, exploration and production optimization at core fields [4].

According to experts, the total oil reserves category proved plus probable (2P) JSC "Exploration Production "KazMunayGas" as of the end of 2011 amounted to $\$ 225,816$ million tons (1,661 billion barrels), excluding shares of KMG in companies "Kazgermunai" (KGM), CCEL (CCEL) and "PetroKazakhstanink" (PKI) in comparison wtih 232,082 million tons (1,707 billion barrels) at the end of 2010. In 2013, they plan to increase oil production by $2 \%$ to 13.5 million tons. Keeping the pace of oil production at the level of last year, JSC "KazMunaiGas" would ensure the scope of work at least a quarter of a century. But according to their long-term development strategy, the Company continues to explore, to expand the volume of hydrocarbon production, to increase profitability of existing assets and develop new business areas [4].

The company is subject to a number of risks, including risks of environment, market, operational, financial, investment and risks of corporate management. The company exercises risk management within Policy of risk management. The policy of the Company in the field of risk management is directed on growth of joint-stock cost and improvement of quality of corporate management by identification of risks, an assessment, and the analysis of their importance, development of measures for their minimization and control of execution of actions for risks minimization.

Market risks. Risks of an adverse effect of the change in price for oil, exchange rates, and interest rates belong to market category. The company carries out wholesale supply of oil, both on internal, and in foreign markets. The main possible deterioration, both for internal, and for foreign markets reduction of prices of oil, which differs in considerable volatility owing to a number of factors is: balance of supply and demand, influence and policy of the main oil-producing countries, a political situation in the main regions of production of energy carriers. Decrease in the world prices for oil substantially will affect deterioration of financial performance of the Company. The company doesn't resort to hedging of risks of reduction of prices of oil at the moment, but in each situation uses the internal instruments of management of expenses allowing reducing negative influence of this risk. 
Inflationary risks. The company conducts the primary activity in Kazakhstan and uses tenge, as the main currency for calculations. The expenses connected with payment of a salary, costs of the electric power, costs of logistic services are sensitive to inflation of tenge.

Interest rate risks. Activity of the Company is subject to risk of change of interest rates that can negatively be reflected in the cost of placement of temporarily free money and, respectively, in financial results activity of the Company.

Currency risks. Currency risk - fluctuation of exchange rates, which makes multidirectional impact on financial activity of the Company. The considerable part of the income of the Company is nominated in US dollars or attached to US dollar. The part of expenses of the Company is nominated in foreign currency, or otherwise, significantly depends on rate fluctuation of foreign currencies (generally it is US dollar, to a lesser extent euro and ruble) concerning tenge. Now the most part of the current expenses of the Company is paid for the prices established in tenge.

The dollar rate increase will make more profitable oil export.

In case of negative influence of change of interest rates and an exchange rate the Company will carry out the following actions for decrease in negative consequences: - expansion of a circle of bank partners, first of all, at the expense of institutes, the least affected from the current world financial crisis;

large-scale use of the instruments of trade financing (letters of credit, guarantees) allowing to reduce dependence of activity of the Company on base interest rates. Such indicators of financial statements of the Company, which can change in a result of influence of the specified financial risks:

$$
\begin{array}{ll}
\text { - } & \text { net profit; } \\
\text { - } & \text { revenue; } \\
\text { - } & \text { prime cost } \\
\text { - } & \text { receivables. }
\end{array}
$$

The operations, which connected with the movement of material and cash flows with contractors since the financial institutions serving financial streams of the Company, are subject to credit risks and finishing the buyers of the final products and contractors rendering various company services. The effective centralized control system of money realized by treasury of the Company allows minimizing credit risks [5].

Table 1. Financial risks, probability of their emergence and nature of change in the reporting

\begin{tabular}{lll}
\hline \multicolumn{1}{c}{ Risk } & Probability of emergence & Nature of change \\
\hline $\begin{array}{l}\text { Falling of rates on deposits of banks } \\
\text { Normal }\end{array}$ & $\begin{array}{l}\text { Decrease in profit owing to falling of the } \\
\text { income on placement of temporarily } \\
\text { available monetary funds }\end{array}$ \\
$\begin{array}{l}\text { Currency risk } \\
\text { (risk of devaluation of a rate of tenge } \\
\text { on the relation to euro and dollar of the }\end{array}$ & $\begin{array}{l}\text { Growth of costs of the acquired } \\
\text { equipment }- \text { increase in depreciation } \\
\text { assignments }\end{array}$ \\
$\begin{array}{l}\text { Inflationary risks } \\
\text { Credit risk }\end{array}$ & $\begin{array}{l}\text { Normal } \\
\text { Source: it is made by the author on a basis of data of the official site of KMG }\end{array}$ \\
\hline
\end{tabular}

Tax risks. The tax system of RK is characterized by small volumes of law-enforcement practice concerning recently adopted normative legal acts. It is also characterized by risk of additional accrual of the taxes, penalties and penalty fee based on illegal interpretation of the legislation. These factors complicate planning of tax expenses of the Company. Management of the Company develops the actions for minimization of the specified risk based on participation in work on improvement of quality of both the most Tax Code, and amendments to it. Besides, the Company continues to defend the interests in courts.

Change of rules of customs control and duties. As the Company carries out the foreign trade activity, change of rules of customs control, ITP volatility, lack of a transparent formula of calculation of ITP can have an adverse 
effect on financial results of the Company. At the same time, the Company carries out continuous monitoring of changes of the current legislation of RK and considers them in the activity that allows minimizing the risks connected with the specified changes.

Operational risks. The main operational risks of the Company occur in the plane of exploration and production and are connected with implementation of continuous activity of the Company. The list of key operational risks, which the Company allocates considerable resources is given below and pays them essential attention for minimization, both in the daily activity, and in the course of planning and an assessment of efficiency of activity.

Investment risks. The major factors influencing investment activity of the Company are:

- Limitation of new assets, available to acquisition, on the land in Kazakhstan.

- Increase in the competition from the large international oil and gas companies for access to oil and gas assets.

- Lack of own highly effective service examination giving the chance of KMG to participate in sea projects in Kazakhstan and also attractive foreign projects. Besides, KMG is the largest oil and gas extraction company controlled by the Government of Kazakhstan. In this regard, the state represented by of "Samruk-Kazyna" and KMG Oil Company can have impact on KMG in interests of the state in general, which can contradict interests of shareholders of KMG. All these factors, both separately, and in total, can lead to underestimation/revaluation of appeal of projects, inefficient investment decisions and, as a result, to reduction of a stock rate and falling of cost of the Company.

Risks of Corporate management. One of the essential factor, which influence effective activity of the Company decrease, is institutional capacity. Highly qualified personnel is competitive advantage and a basis of achievement of strategic objectives of the Company. Annually the Company faces a problem of attraction of shots with the corresponding qualification. It is connected, first of all, with impossibility of recruiting of the personnel, in view of deficiency of a necessary professional category in labor market in certain regions. A number of measures directed on increase of loyalty, level of motivation and professional level of the personnel is developed for decrease in this risk in the Company. Besides, the essential attention to increase of leader competences of management and to formation of a personnel reserve is paid.

Fraud and corruption. Distribution of resources not in the best interests of the Company, causing damage of the Company for obtaining personal benefit, any facts of manifestation of corruption are absolutely unacceptable in activity of the Company regardless of the extent of financial damage. The company takes all possible actions for prevention of illegal activity and causing reputation damage of the Company. The company is subject of the Law RK "About Corruption", and also, come into force in July, 2011, the Law of Great Britain "About bribery" (UK Bribery Act 2010) and builds the domestic policy and procedures in strict accordance with the above-named laws.

Table 2. Financial and economic indicators of JSC "KazMunaiGas"

\begin{tabular}{ccccc}
\hline & 2009 & 2010 & 2011 & 2012 \\
\hline ROS & $31,90 \%$ & $30,65 \%$ & $22,74 \%$ & $18,75 \%$ \\
ROA & $11,98 \%$ & $13,07 \%$ & $10,64 \%$ & $9,56 \%$ \\
ROE & $20,96 \%$ & $20,22 \%$ & $16,09 \%$ & $12,02 \%$ \\
Coef. absolute liquidity & 0,65 & 0,58 & 1,22 & 0,84 \\
Coef. current liquidity & 4,50 & 3,64 & 4,02 & 5,06 \\
The share of ZK in Assets & $22,58 \%$ & $18,84 \%$ & $15,73 \%$ & $14,47 \%$ \\
\hline
\end{tabular}

*Source: Compiled by the author based on annual report of KMG in 2012

From Table 2, a decrease in the turnover ratio for some indicators, in particular: the turnover ratio of assets in 2009 decreased by 0.23 (from 0.65 to 0.42 ), accounts receivable - by 2.81 (from 13,76 to 10,96 ). The trend continued in 2010 , if not only asset turnover, which increased slightly by 0.03 . As for the other coefficients, and although there was a small decline in the turnover rate of stocks in 2009. (from 22,87 to 22,09), in 2010 this ratio increased to 2.54 . The turnover ratio accounts payable increased in $2009-2010$ by 1.1 and 0.44 respectively. This is a negative factor for the company as a reduction of the coefficients of turnover tells about the slowdown in the turnover of capital and the production process. The economic effect of this factor is expressed in relative release of funds from circulation, and increase revenue and profit. In this case there is a decrease in the release of funds when revenue growth. 


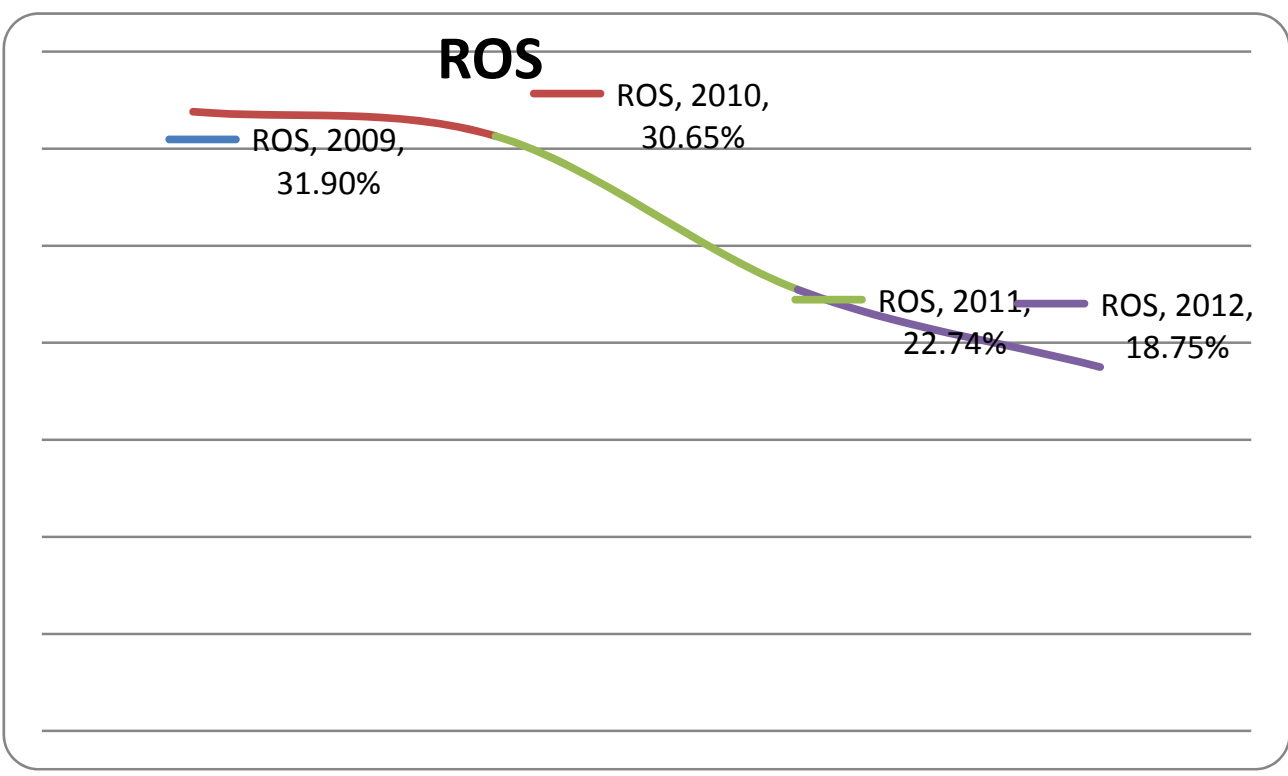

Figure 2. The profitability dynamics of JSC "EP "KazMunaiGas".

In general, by estimating financial and economic indicators of the enterprise, it can be concluded: the financial situation in the normal range and profit growth open up additional reserves. For JSC "EP "KazMunaiGas" it is necessary to conduct activities to reduce operating and non-operating expenses. The coefficient of financial stability - a summary measure, its increase and norm excess are rather a positive factor for the company, because the increase in this ratio speaks a stable position of the enterprise.

Assessment of the financial risks of JSC "EP "KazMunaiGas" by the method of quantitative estimates of VaR. The methodology of Value at Risk has become widely spread among financial institutions from the mid 90-ies of XX century. This method was first recommended by the Group of Thirty (G30) in 1993 in "Derivatives: Practice and Principles". Further, a contribution to the study of VaR estimation made one of the largest investment companies J. P. Morgan in the work of RiskMetrics. And, as a result, in 1995 the Basel Committee on banking supervision recommended the VaR methodology as the main approach to risk assessment.

VaR is the value expressed in the base currency, which will not exceed expected during this time period loss with a given probability. $\mathrm{VaR}$ is a universal method of calculating various types of risk:

- price risk - risk of changes in value of a financial asset price in the market;

- currency risk - risk of changes in market exchange rate of the national currency to the currency of another country;

- credit risk - risk arising from partial or complete insolvency of the borrower under the loan;

- liquidity risk - risk associated with the impossibility of selling financial asset or the implementation of large losses arising from the disposal of assets due to a big difference of value of purchase/sale of existing on the market.

Traditionally, methods of calculating VaR are divided into:

- Historical;

- Parametric (the variance-covariance model);

- Simulation method (Monte Carlo method).

- Historical simulation method.

Estimation by VAR method of the historical simulation in the classic version is as follows. The original number of indicators is determined in the first stage - value of the portfolio for all documented in the historical period of the states of the market. (In our case daily currency exchange rates change)

In the second stage, the obtained time series is translated into a series of relative changes according to the formula [7]: 


$$
\Delta_{i}=\frac{y_{i}-y_{i-1}}{y_{i-1}}
$$

To determine the cost of risk, namely in oil prices by the method of Value at Risk (VaR), were historical annual measure of the price of Brent crude oil. In the third stage, the changes are ordered, and are cleared at the worst part of the values that exceed the established confidence level. The worst of the left value corresponds to the maximum probable loss value within an accepted confidence level, i.e. VaR.

The final fourth stage, the obtained relative VAR is reduced to absolute monetary equivalent.

To determine the cost of risk, namely in oil prices by the method of Value at Risk (VaR), were historical annual measure of the price of Brent crude oil.

$\mathrm{VaR}$ is characterized by three parameters:

1) The time horizon that depends on the situation under consideration. Documents on the Basel -10 days, by the method of Risk Metrics is 1 day. More common calculation is 1-day horizon. 10 days is used to calculate the magnitude of the capital covering possible losses.

2) Confidence interval (confidence level) - the level of acceptable risk. Documents on the Basel used the value of $99 \%$, in the RiskMetrics system is $95 \%$.

3) The base currency in which the indicator is measured.

The calculation begins with the computation of mathematical expectation of daily price changes effective from 01 January 2012 to the present day. Mathematical expectation is the average value of a random variable, the probability distribution of a random variable considered in probability theory. In this case, the mathematical expectation is equal to $-0,04 \%$.

Next step is a determination of the standard deviation. Standard deviation is a measure of dispersion of values of a random variable about its expected value. In this case, the standard deviation equals to $1.35 \%$.

Then the Quantile should be found for our model. Quantile in mathematical statistics is the value that a given random variable does not exceed with a fixed probability. To determine the VaR, we apply a probability of $99 \%$ according to the Basel documents. In this case, the quantile equals to $-3.2 \%$.

So, first, calculate the price for the day ahead according to the method of Risk Metrics. The price of Brent crude oil for April 22, 2013 equals to $\$ 99,07$. Multiplying this price by quantile and the value $X(1)=95,92$, it says that in the course of the next day, the price of oil will not fall below the values in 95,92 tenge with a probability of $99 \%$.

According to the Basel documents a time horizon that depends on the situation under consideration is 10 days. Further multiplying this price by quantile and the square root of ten, we get the values of $X(10)=89,11$, it says that in the next ten days, the price of oil will not fall below the values in 89,11 tenge c a probability of $99 \%$.

Therefore, based on the foregoing, the company can predict future cash flows and estimate future price risks for further hedging.

Stress testing of financial risks of JSC "EP "KazMunaiGas". Today, in the world of global structural and technological changes, where an incident in one part of the planet can cause the amplitude of price variations around the world, problems occur that it is impossible to predict. Instead of doing financial projections for the method of "best estimates", the company or its regulators prefer stress testing. Stress testing is one form of testing that is used to determine the stability of the system or a legal entity under conditions exceeding the limits of normal operation. Especially the behavior of financial instruments in the case of a specific stressful situation are viewed during stress-testing, for example:

- What happens if stock markets fall more than $\mathrm{X} \%$ this year?

- What happens if GDP falls by Z\% in a given year?

- What happens if interest rates rise, at least $Y \%$ ?

- What if half of the instruments in the portfolio will be terminated in five years?

- What will happen if the price of oil will increase by $200 \%$ ?

This type of analysis is becoming more common, and is used by various government agencies (e.g. the FSA in the UK) and intergovernmental organizations (such as the EBA and the international monetary Fund) as the 
regulatory requirements on certain financial institutions to ensure adequate allocation of capital to cover potential losses incurred during extreme, but plausible events. The emphasis on the adequacy (adjusted for risk) of the definition of capital has been strengthened by changes in banking legislation (Basel II). Model stress testing usually allow you not only to take into account individual risk factors, but a combination of different events. Usually you can check the current impact of known historical scenarios on the liquidity position of the institution. Models of the stress test show how the portfolio is sustainable in the implementation of forecasts and provide insight about possible vulnerabilities. Although extreme events cannot be predicted, the study of their impact on the effectiveness of the organization strengthens the understanding of the situation. Model of the stress test determines the script that uses a special algorithm to determine the expected impact on the return of the portfolio in the case scenario.

There are three types of scenarios:

Extreme events: as events often use already occurring historical event.

Shock risk factors shock of any factor in the chosen model of risk for a user-defined amount. The impact factor remains the same, and connection with the risk factor is used to assess the return covariance matrix.

External risk factor: a risk factor is any macroeconomic index (e.g., oil prices, real estate prices), or set the index (e.g., exchange rates).

This section is devoted to determining the stability of the system KMG EP to different structural macro and micro-economic risks. The dependent variable in this model will be the annual revenue of the company. The first step should construct a simple model for regression.

Pair regression is a regression between two variables y and $x$, i.e. a model of the form[9]:

$\mathrm{y}(\mathrm{x})=\mathrm{f}^{\wedge}(\mathrm{x}),(2)$

where $\mathrm{y}$ is the dependent variable (effective basis); $\mathrm{x}$ - independent, or explanatory, variable (trait-factor). The sign $" \wedge "$ means that between the variables $\mathrm{x}$ and $\mathrm{y}$ there is no strict functional dependency, therefore, almost in every case the value of $y$ is the sum of two terms:

$\mathrm{y}=\mathrm{yx}+\varepsilon,(3)$

where $y$ is the actual value of resultant; $y x$ - theoretical value of the effective feature, found on the basis of the regression equation; $\varepsilon$ is a random variable characterizing the deviation of the real values of the effective feature from the theoretical, was found in the regression equation.

The selection of data. As previously mentioned, pair regression is a regression between two variables $\mathrm{y}$ and $\mathrm{x}$. Here to determine the change which metrics are most susceptible to the change of the company's revenues.

Table 3. Factors affecting the change of the company's revenues

\begin{tabular}{llllll}
\hline Year & Revenue of EP KMG, mln tenge & Brent average price & EUR/USD & Inflation \% KZ & USD/Tenge \\
\hline 2000 & & 28,98 & 0,92 & 9,80 & 142,13 \\
2001 & 25,05 & 0,90 & 6,40 & 146,74 \\
2002 & & 25,41 & 0,95 & 6,60 & 153,28 \\
2003 & 177757 & 31,07 & 1,13 & 6,80 & 149,58 \\
2004 & 237103 & 41,61 & 1,24 & 6,70 & 136,04 \\
2005 & 346429 & 59,40 & 1,24 & 7,50 & 132,88 \\
2006 & 412208 & 69,11 & 1,26 & 8,40 & 126,09 \\
2007 & 486975 & 78,00 & 1,37 & 18,80 & 122,55 \\
2008 & 604993 & 97,22 & 1,47 & 9,50 & 120,30 \\
2009 & 485493 & 61,68 & 1,39 & 6,20 & 147,50 \\
2010 & 609242 & 79,11 & 1,33 & 7,80 & 147,35 \\
2011 & 721194 & 110,91 & 1,39 & 7,40 & 146,62 \\
2012 & 797170 & 112,25 & 1,29 & 6,00 & 149,11 \\
\hline
\end{tabular}


This table shows the data directly and/or indirectly have an impact on the company's revenue. Data evaluation impact is necessary to navigate through the calculation of the correlation coefficient. Correlation is a statistical relationship of two or more random variables (or values that can with some reasonable degree of accuracy, be considered as such).

The correlation coefficient is calculated by the formula [10]:

$$
r=\frac{\sum_{i=1}^{n}\left(x_{n}-\bar{x}\right)\left(y_{n}-\bar{y}\right)}{n \sigma_{x} \sigma_{y}}
$$

where $\mathrm{n}$ is the number of observations, $\mathrm{x}$ is the input variable, $\mathrm{y}$ is the output variable. The values of the correlation coefficient are always in the range from -1 to 1 and are interpreted as follows:

- if the correlation coefficient is close to 1 , then between variables there is a positive correlation. In other words, there is a high degree of connection input and output variables. In this case, if the values of the input variable $x$ will increase, and the output variable will also increase;

- if the correlation coefficient is close to -1 , it means that between the variables observed negative correlation. In other words, the behavior of the output variable will be opposite to the behavior of the input. If the value of $x$ increases then y will decrease, and Vice versa;

- intermediate values close to 0 will indicate a weak correlation between the variables and, respectively, low dependence. In other words, the behavior of the input variable $\mathrm{x}$ is completely (or almost completely) to affect the behavior of $y$.

Table 4. Correlation coefficients between the factors

\begin{tabular}{ll}
\hline The correlation coefficient of KMG EP's Revenue with Brent & 0,97 \\
The correlation coefficient of KMG EP's Revenue with EUR/USD & 0,66 \\
The correlation coefficient of KMG EP's Revenue with Inflation & 0,02 \\
The correlation coefficient of KMG EP's Revenue with USD/Tenge & 0,14 \\
\hline
\end{tabular}

Table 4 shows that the greatest impact on revenue have oil prices only -0.97 and the Euro/Dollar $-0,66$. Performing calculations according to the above calculation of the regression, we obtain the following stress-testing with the following variations in the prices of Brent crude oil:

1) when the price of Brent crude oil to $\$ 115$ the company's revenue is $779905+\varepsilon$ million tenge;

2) when the price of Brent crude oil $\$ 80$ the company's revenue is $530376+\varepsilon$ million tenge;

3) when the price of Brent crude oil to $\$ 40$ the company's revenue is $245200+\varepsilon$ a million tenge;

4) when the price of Brent crude oil $\$ 130$ the company's revenue is $886846+\varepsilon$ million tenge;

5) when the price of Brent crude oil $\$ 150$ the company's revenue is $1434029+\varepsilon$ million tenge;

Following the stress-testing with regression, will be with variations in the exchange rate Euro/Dollar:

1) when the exchange rate Euro/Dollar $\$ 1,15$ the company's revenue is $271499+\varepsilon$ million tenge;

2) when the exchange rate Euro/Dollar to $\$ 1.30$ on revenue of the company is $472501+\varepsilon$ million tenge;

3 ) when the exchange rate Euro/Dollar at $\$ 1.40$ to the company's revenue is $606501+\varepsilon$ million tenge;

4) when the exchange rate Euro/Dollar to $\$ 1.50$ to the company's revenue is $740502+\varepsilon$ million tenge;

5) when the exchange rate Euro/Dollar $\$ 1,60$ the company's revenue is $874503+\varepsilon$ million tenge;

As can be seen from the calculations, the company's beneficial to commodity prices were high and the Dollar against the Euro was low. The first situation is extremely clear, the second is that when the Euro is worth more, then the European companies and residents will have more free funds that they can allocate to the cost of petrol, thereby spurring the consumption of petroleum products in the EU.

\section{The strategy of hedging price risks of JSC "KMG EP".}


Hedging is a way to protect against the impact of changes in prices, widely used, when prices are volatile. The concept of hedging is to take a contract position opposite the position from which the associated risk. Therefore, choosing the right strategy during hedging price volatility is associated with which position is hedged. For example, an oil producer may feel that prices will fall, and he needs to fix the future price of sale of the goods at the current level. He can sell a certain amount of futures and forward contracts, equivalent to the value of the goods, which he will deliver if he wants to hedge against a possible drop in prices in the future. Giving preference to this or any other contract, the hedger selects the one whose price most closely consistent with the price charged to them in contracts for the sale of.

The nature of the hedging operation is divided into 2 groups:

1) long (long hedge) hedging purchase, that is the conclusion of the consumer/merchant contracts to hedge against the possibility of increasing prices when buying in the future of the relevant product;

2) short (short hedge) a hedge of the sale, we have the conclusion of the manufacturer/ goods owner contract to protect against a possible price decline in the sale of future goods, shall be required to supply at a certain date. In the case of price reduction on merchandise loss due to the decrease in the prices of stocks it is balanced by gains from short positions in the futures market.

A perfect hedge is an abstract concept, implying that the hedge on the futures market eliminates the risk of the spot transaction. In principle, hedge, close to the ideal, is possible, but it is believed that genuine perfect hedge a rarity, because the prices on spot and "paper" transactions never move in parallel. The closer a futures contract or other hedging instrument to the physical specifications of the product, the better the hedge.

Basis risk - change the difference between the price of physical goods and the price of corn futures[13].

The results of the impact of potential changes to the basis for hedgers, covering both short and long positions are presented in Table 5 .

Table 5. Results of the effects of changes in the basis for hedgers

\begin{tabular}{|c|c|c|c|c|}
\hline & price increase & & prices decrease & \\
\hline $\begin{array}{l}\text { Position on spot and } \\
\text { "paper" trades }\end{array}$ & $\begin{array}{ll}\text { 1) Spot } & \text { prices } \\
\text { grow } & \text { slower } \\
\text { futures } & \end{array}$ & $\begin{array}{l}\text { 2) Spot } \quad \text { price } \\
\text { futures are } \\
\text { faster }\end{array}$ & $\begin{array}{l}\text { 3) Spot prices } \\
\text { futures fall slower }\end{array}$ & $\begin{array}{l}\text { 4) Spot price } \\
\text { futures fall faster }\end{array}$ \\
\hline $\begin{array}{l}\text { Bought a spot contracts - } \\
\text { sold futures contracts }\end{array}$ & Loss & Profit & Profit & Loss \\
\hline $\begin{array}{l}\text { Sold spot contracts - } \\
\text { bought futures contracts }\end{array}$ & Profit & Loss & Loss & Profit \\
\hline
\end{tabular}

Thus, in the market for "intervention" hedgers-sellers (short hedgers) always profit during time basis, and hedgers-buyers (long hedgers) always lose. For companies that have stocks of goods, there is a real incentive to implement hedging with futures markets. The result is a payment of all or part of the cost of storage due to the futures market. At the same time in the market "bakwagen" short hedgers will always bear the losses if cash and futures prices to converge, and long hedgers will make a profit.

Analysis on insurance strategies price risk allowed us to draw the following conclusions.

1. The crude oil market participants are actively using exchange contracts (sale of "paper" oil) for insurance of risks of price changes on the supply of physical goods. Also forward contracts are used widely, to ensure future supplies with a contract price fixed at the time of conclusion

2. There are different options of hedging strategies (risk insurance). Their choice depends on the market conditions (the ratio of supply and demand).

3. Hedging is an important aspect of the oil trade, as at present oil prices are highly volatile, and the companies, making deals on big expensive party, want to protect themselves from financial loss and get the most profit from the sale of their products.

4. It is impossible to completely avoid price risk, and there is a probabilty of loss of additional profit, but hedging helps to avoid unwanted financial losses, to provide greater stability and flexibility in planning.

Studying the insurance strategies of price risks for the export of the company allowed to draw the following 
conclusions:

1. Most Russian companies are not familiar with the practice of hedging, they formed the wrong impression about it, therefore there is a mixture of the concepts of hedging and speculation and fear of "losing" on the hedge.

2. For a more successful hedging practice companies need the involvement of professional consultants, seminars, and in consequence create their own hedging units, which include specialists in risk management, Finance, accounting and law.

3. Hedging requires an elaboration of its objectives and implementation, contrasting the need for hedging purposes of this particular company.

4. Successful and appropriate adoption of hedging will reduce profit fluctuations, improve the controllability of the production, increase the capital, stabilize the yield.

5. Companies, engaged in export of oil and oil products, have an necessity in hedging due to the unstable prices for raw materials, as well as significant trade volumes, profits and possible losses.

6. It must be remembered that the aim of hedging is not profit, but reducing the financial risks, minimization of potential losses, and hedging assumes full legal and financial validity of transactions.

\section{References}

Abdrahmanova, G. T. (2003). Hedzhirovanie: koncepcija, strategija i praktika. Almaty: LEM.

Bajmuratov, U. (n. d.). Den'gi i finansy: nelinejnaja sistema Tom 1.

Bobylev, Ju. N. (2006). Faktory formirovanija cen na neft'. M.: IJePP.

Bobylev, Ju. N., \& Chetverikov, D. N. (2006). Faktory razvitija rynka nefti. IJePP.

Chelekbaj, A. D. (2007). Risk-menedzhment $v$ denezhno-kreditnoj i innovacionnoj dejatel'nosti: teorija, mirovoj opyt i praktika Kazahstana, uchebnoe posobie, Almaty.

InfoTJeK-Terminal. Informacionnye uslugi dlja neftegazovogo biznesa. Retrieved from http://www.itek.ru/

Iskakov, U. M., Bohaev, D. T., \& Ruzieva, Je. A. (2012). Finansovye rynki i posredniki: uchebnik. pererab. Almaty: Jekonomika.

Jablukova, R. Z. (2004). Finansovyj menedzhment v voprosah i otvetah: Ucheb. Posobie. TK Velbi, Izd-vl Prospekt, $256 \mathrm{~s}$.

Neft', Gaz i Fondovyj Rynok. Retrieved from http://www.ngfr.ru/

Official site of JSC "KMG".

RiskManage.ru: Hedzhirovanie i metody upravlenija riskami, risk-menedzhment, stat'i po analizu riskov. Retrieved from http://www.riskmanage.ru/

The World Factbook, CIA. Retrieved from https:/www.cia.gov/library/publications/the-world-factbook/ rankorder/rankorderguide.html

US Energy Information Administration. Retrieved from http://www.eia.doe.gov/

\section{Copyrights}

Copyright for this article is retained by the author(s), with first publication rights granted to the journal.

This is an open-access article distributed under the terms and conditions of the Creative Commons Attribution license (http://creativecommons.org/licenses/by/3.0/). 